\title{
EFISIENSI REPRODUKSI SAPI PERANAKAN LIMOUSIN AKSEPTOR INSEMINASI BUATAN DI KECAMATAN TIKUNG, KABUPATEN LAMONGAN TAHUN 2016
}

\section{REPRODUCTIVE EFFICIENCY OF ARTIFICIAL INSEMINATION ACCEPTOR ON FILIAL LIMOUSINE IN TIKUNG SUB-DISTRICT, LAMONGAN DISTRICTS AT 2016}

\author{
Vina Ari Prastyorini ${ }^{1)}$, Koesnoto Supranianondo' ${ }^{2)}$, Erma Safitri ${ }^{3)}$, \\ Tjuk Imam Restiadi ${ }^{4)}$, Wurlina ${ }^{5)}$, Tatik Hernawati ${ }^{6)}$ \\ ${ }^{1)}$ Student, ${ }^{2)}$ Veterinary Husbandry Department ${ }^{3)}$ Veterinary Reproduction Department \\ Faculty of Veterinary Medicine, Airlangga University \\ email: vinaariprastyorini@gmail.com
}

\begin{abstract}
The purpose of this study was known the difference of reproductive performans Limousine Cross Breed that haved artificial insemination from diffrence straw from BBIB Singosari and BBIB Lembang covering Conception Rate, Service per Conception, and Calving Rate in period 2016th. This study uses survey research which data from primary and secondary. Primary data were obtained from interview with Limousine Cross Breed breeders and secondary data were obtained from artificial insemination officer's record. The observed variables are Conception rate $(\mathrm{CR})$, Service per conception $(\mathrm{S} / \mathrm{C})$ and Calving rate $(\mathrm{CvR})$. Data were analyzed descriptive that average and Chi Square.Result of research showed no significant difference ( $p>0.05$ ) on $\mathrm{CR}, \mathrm{S} / \mathrm{C}$ and $\mathrm{CvR}$ between Limousin cross breed cows that haved artificial insemination from BBIB Singosari and BIB Lembang.
\end{abstract}

Keyword : Conception rate (CR), Service per conception (S/C), Calving rate (CvR), Filial Limousine, Artificial Insemination.

\section{Pendahuluan}

Peningkatan jumlah penduduk Indonesia dan kesadaran terhadap pentingnya protein hewani menyebabkan peningkatan konsumsi protein hewani, khususnya daging sapi. Angka kebutuhan yang tinggi tidak diikuti dengan peningkatan daging sapi potong, sehingga kekurangan tersebut pada saat ini dipenuhi dari daging sapi impor (Atmakusuma dkk., 2014). Produksi daging sapi di Indonesia menurut Pusat Data dan Sistem Informasi Pertanian Sekretariat Jenderal Kementerian Pertanian (2016) mencapai 524,11 ribu ton pada tahun 2016 untuk memenuhi konsumsi daging sapi sebesar 2,40 kg/kapita/tahun. Angka tersebut menunjukkan bahwa kebutuhan konsumsi daging di Indonesia masih belum terpenuhi. Kondisi yang demikian memberi peluang pemenuhan pengembangan usaha budidaya ternak sapi potong. Dalam upaya menghadapi kebutuhan daging lokal yang terus meningkat (Winarso, 2005). Peningkatan populasi ternak sapi memerlukan usaha peningkatan efisiensi reproduksi dan fertilitas ternak (Hafez, 2000). Peningkatan efisiensi reproduksi pada ternak sapi dapat dilakukan melalui Inseminasi buatan (IB). Inseminasi buatan (IB) merupakan program yang banyak dikenal oleh peternak sebagai teknologi reproduksi yang efektif karena dapat menghasilkan ternak dengan kualitas yang unggul dalam jumlah yang besar melalui pemanfaatan pejantan unggul (Susilawati, 2011). Hariadi (2011) menyebutkan bahwa efisiensi reproduksi ternak didasarkan pada lima hal yaitu angka kebuntingan (conception rate/CR), jarak antar kelahiran (calving interval/CI), jarak waktu antara melahirkan sampai bunting kembali (service periode,/days open), angka inseminasi per kebuntingan (service per conception/ S/C), dan angka kelahiran (calving rate/CvR). Salah satu di kabupaten Lamongan daerah yang menerapkan teknologi IB adalah kecamatan Tikung. Daerah ini memiliki komoditas sapi potong sebanyak 5.827 ekor dari total 101.790 ekor sapi potong yang dimiliki kabupaten Lamo- 
ngan. (Badan Pusat Statistik Lamongan, 2016). Kecamatan Tikung merupakan daerah yang menggunakan dua asal straw yang berbeda dalam pelaksanaan Inseminasi Buatan, yaitu straw asal BBIB Singosari dan BIB Lembang. Hal tersebut dapat dijadikan evaluasi mengenai efektifitas asal straw semen manakah yang lebih baik dalam menghasilkan kebuntingan pada sapi khususnya sapi Limousin. Hal ini dikarenakan sapi Limousin merupakan sapi yang paling cepat mengalami pertambahan berat badan dan menghasilkan persentase daging yang cukup besar.

\section{Materi dan Metode Penelitian}

Materi yang digunakan dalam penelitian ini adalah 918 peranakan sapi Limousin yang diinseminasi menggunakan straw asal BBIB Singosari dan 589 peranakan sapi Limousin yang diinseminasi menggunakan straw asal BIB Lembang. Metode yang digunakan dalam penelitian ini adalah metode survei dengan mengambil data berupa data primer dari catatan inseminator dan dari catatan dinas peternakan dan wawancara pada peternak di kecamatan Tikung, Kabupaten Lamongan.

\section{Analisis Data}

Data Primer dan data sekunder yang telah terkumpul dari catatan reproduksi Inseminator dan wawancara survey peternak yang dilakukan di kecamatan Tikung, kabupaten Lamongan di tabulasi kemudian diolah menggunakan analisis deskriptif untuk mendapatkan angka Conception Rate $(C R)$,Service per Conception $(S / C)$ dan Calving Rate $(C \nu R)$. Kemu-dian dari data dibandingkan angka Conception Rate $(C R)$, Service per Conception $(S / C)$ dan Calving Rate $(C v R)$ dari dua jenis straw Balai Inseminasi Buatan yang berbeda dengan uji Chi Square.

\section{Hasil dan Pembahasan}

Tabel 1. Nilai efisiensi reproduksi sapi peranakan limousin akseptor Inseminasi Buatan di kecamatan Tikung kabupaten Lamongan 2016

\begin{tabular}{|c|c|c|c|}
\hline Variabel & $\begin{array}{c}\text { Asal BBIB } \\
\text { Singosari }\end{array}$ & $\begin{array}{c}\text { Asal } \\
\text { BBIB } \\
\text { Lembang }\end{array}$ & $\begin{array}{c}\text { Nilai } \\
\text { Normal }\end{array}$ \\
\hline $\begin{array}{c}\text { Conception } \\
\text { Rate }\end{array}$ & $64,70 \%$ & $67.06 \%$ & $65-75 \%$ \\
\hline $\begin{array}{c}\text { Service per } \\
\text { Conception }\end{array}$ & 1,683 & 1,623 & $1,65-2,0$ \\
\hline $\begin{array}{c}\text { Calving } \\
\text { Rate }\end{array}$ & $61,76 \%$ & $63,67 \%$ & $55-65 \%$ \\
\hline
\end{tabular}

\section{Conception Rate (CR)}

Conception rate adalalah persentase sapi betina yang bunting pada inseminasi pertama dari sejumlah keseluruhan ternak betina yang diinseminasi (Susilawati, 2013). Nilai CR yang baik menurut Hariadi dkk,. (2011) adalah 65-75\%. Dari hasil analisis dan perhitungan didapatkan nilai Conception rate dari sapi peranakan Limousin yang diinseminasi dengan semen asal BBIB Singosari mempunyai rata-rata nilai sebesar $64,70 \%$ dan yang diinseminasi dengan semen asal BBIB Lembang mempunyai rata rata nilai sebesar $67,06 \%$. Maka dapat dikatakan bahwa nilai kebuntingan hasil inseminasi pertama di kecamatan Tikung, kabupaten Lamongan tergolong ideal dan cukup normal untuk Conception rate pada umumnya baik yang melakukan IB menggunakan straw asal BBIB Singosari maupun me-nggunakan straw asal BBIB Lembang.

Pada penelitian sebelumnya oleh Fauziah dkk. pada tahun 2015 di daerah kecamatan Paciran, kabupaten Lamongan di dapatkan nilai CR 73,34\% untuk Sapi peranakan Limousin, angka tersebut sudah diakatakan ideal untuk nilai $\mathrm{CR}$ menurut Hariadi dkk., (2011) yang berpendapat bahwa nilai CR yang baik adalah sekitar $65-75 \%$. Nilai CR yang tinggi dapa dikarenakan kesuburan pejantan, kesuburan betina, teknik inseminasi dan kete-patan waktu birahi (Susilawati, 2011).

Rata-rata CR hasil IB tersebut dapat disimpulkan bahwa IB menggunakan straw semen asal BBIB Lembang mempunyai nilai $C R$ yang tidak berbeda nyata $(p>0,05)$ dengan nilai $C R$ yang menggunakan straw semen dari BBIB Singosari.

Hal yang dapat mempengaruhi nilai $C R$ yang tinggi adalah inseminator yang melakukan Inseminasi buatan di darah tersebut. Seperti penelitian yang dilakukan oleh Herawati (2012) yang menunjukkan pengalaman bekerja seorang inseminator menun- 
jukkan perbedaan hasil kebuntingan. Makin berpengalaman dan makin lama menjadi seorang inseminator maka nilai kebuntingan yang didapatkan makin tinggi pula Inseminator yang melaksanakan IB di kecamatan Tikung, kabupaten Lamongan mempunyai pengalaman lebih dari 40 tahun dan memiliki sertifikat IB, PKR dan ITR. Selain pengalaman Inseminator dalam melaksanakan IB, pengalama berternak juga menjadi penyebab nilai CR yang tinggi di suatu wilayah. Pengalaman berternak di kecamatan Tikung, kabupaten Lamongan sebanyak $60 \%$ dari responden kuisoner telah berternak selama lebih dari 10 tahun, dan banyak dari responden mengatakan telah melakukan kegiatan berternak sapi secara turun menurun sehingga hampir semua peternak mengetahui bagaimana manajemen pemeliharaan sapi yang baik untuk menghasilkan sapi bunting.

Peternak yang mengetahui sapi mereka bunting akan memperlakukan sapi mereka sedikit berbeda dan menjaga sapi agar tidak terlalu stres dan mendapatkan nutrisi lebih banyak dari biasanya, seperti penambahan dedak yang lebih banyak atau penambahan garam agar konsumsi pakan lebih banyak.

Pemeriksaan kebuntingan yang dilakukan selain dengan bantuan inseminator untuk palpasi rektal rektal, peternak di kecamatan Tikung melihat ciri-ciri kebuntingan sapi secara fisik, antara lain badan sapi yang mulai membesar, bulu yang lebih mengkilap atau dengan memerah susu sapi betina yang telah di IB sekitar tiga bulan sebelumnya, jika saat diperah keluar cairan putih kekuningan maka dapat dipastikan sapi bunting. Namun bebe-rapa peternak yang melihat sapi bunting dari ciri fisik masih memastikan kebuntingan dengan pemeriksaan rektal oleh inseminator pada umur kebuntingan $>4$ bulan.

\section{Service per Conception}

Service per Conception adalah angka yang menunjukkan jumlah inseminasi untuk menghasilkan kebuntingan dari sejumlah pelayanan (service) inseminasi yang dibutuhkan oleh seekor betina sampai terjadinya kebuntingan atau konsepsi (Hafez, 2000). Menurut Jainudeen and Hafez (2008) S/C normal adalah sekitar 1,6-2,1 dan semakin tinggi nilai S/C maka makin rendah kesuburan suatu ternak. Dalam penelitian ini nilai S/C sapi peranakan limousin yang diinseminasi meng-gunakan semen yang berasal dari BBIB Singo-sari mempunyai nilai 1,683 sedangkan yang diinseminasi menggunakan straw semen asal BBIB Lembang mempunyai nilai $\mathrm{S} / \mathrm{C} \quad 1,623$. Sehingga dapat disimpulkan bahwa nilai $\mathrm{S} / \mathrm{C}$ dari sapi yang diinseminasi menggunakan straw semen dari BBIB Singosari mempunyai nilai $\mathrm{S} / \mathrm{C}$ lebih rendah daripada BBIB Lembang. Rendahnya nilai S/C dapat dikarenakan manajemen pakan yang cukup baik dari peter-nak sapi potong di kecamatan Tikung, kabupaten Lamongan yang kebanyakan merupakan petani dan mendapatkan pakan ternak tiap tahun dari limbah pertanian yang cukup melimpah sehingga sapi tidak kekurangan pakan. Sapi yang kekurangan pakan dapat mempengaruhi proses ovulasi, pembuahan dan perkembangan embrio (Hariadi dkk. 2011).

Pakan alternatif dari limbah pertanian ini sering dipakai untuk pengganti pakan sapi adalah limbah dari tanaman kedelai dan limbah kangkung. Limbah pertanian biasanya memiliki kandungan nutrisi yang rendah dan serat kasar yang tinggi, sehingga peternak menambahkan nutrisi dengan penambahan dedak yang dicampur dengan air atau dengan ditambahi dengan garam sehingga konsumsi pakan sapi lebih banyak dan lahap.

Pengetahuan peternak tentang waktu birahi dan tanda tanda birahi juga menjadi penyebab nilai $\mathrm{S} / \mathrm{C}$ yang tinggi, $86 \%$ peternak di kecamatan Tikung kabupaten Lamongan cukup mengetahui tanda tanda birahi karena telah turun temurun berternak sapi. Berdasarkan data responden yang diwawan-cara, sebanyak $88 \%$ akan segera menghubungi inseminator jika sapi mereka birahi dan sisanya akan menunggu esok hari kerena beranggapan jika diinseminasi pada akhir birahi maka kemungkinan bunting lebih besar daripada di awal birahi. Namun beberapa peternak khusus yang mempunyai peternakan intensif memilih untuk menghitung masa birahi dan melakukan IB pada sepertiga masa kebuntingan akhir agar melahirkan pedet jantan.

Beberapa peternak mengaku tidak semua sapi akan langsung bunting pada IB yang pertama, dalam wawancara yang dilakukan terdapat sapi yang mendapatkan kebuntingan setelah IB ke enam tapi pada 
umumnya sapi tidak bunting setelah IB ke empat maka peternak akan segera menjual sapi tersebut karena dinilai tidak menguntungkan. Peternak di kecamatan Tikung, kabupaten Lamongan pada umumnya berprofesi sebagai petani sehingga jika panen tidak terlalu menghasilkan dan jika ada kebutuhan khusus maka sapi bentina produktif yang mereka miliki akan dijual.

\section{Calving Rate}

Calving rate merupakan persentase sapi yang lahir dari total kebuntingan yang berasal dari IB pertama, kedua, ketiga, dan seterusnya. Nilai Calving rate yang didapat dari penelitian adalah $61,76 \%$ untuk sapi yang diinseminasi dengan straw semen dari BBIB Singosari dan 63,67\% untuk sapi yang diinseminasi dengan straw seman dari BBIB Lembang. Keduanya mempunyai nilai CvR yang cukup baik karena berada pada nilai normal dan sudah melebihi $55 \%$. Menurut Hariadi dkk., (2011) nilai Calving rate yang baik adalah sekitar 55-65\%. Terpenuhinya nilai $\mathrm{CvR}$ dibandingkan ankgka normal dikarnakan pengalaman peternak yang berada di kecamatan Tikung, kabupaten Lamongan yang berternak secara turun temurun dan lebih dari 10 tahun. Peternak yang tahu bahwa sapi mereka bunting akan menjaga sapi dengan baik dan memberikan pakan dan pakan tambahan lebih banyak.

Terdapat beberapa laporan abortus menurut inseminator yang sempat melakukan wawancara, namun terjadinya abortus tidak dikarenakan faktor pakan yang jelek atau manajeman pemeliharaan yang buruk. Abortus yang dialami peternak di Kecamatan Tikung, Kabupaten Lamongan biasanya terjadi karena induk sapi yang terlalu muda sudah dikawinkan. Hampir semua sapi yang dijadikan indukan bukan dipelihara sejak pedet, peternak membeli sapi betina muda di pasar hewan atau tempat lainnya karena setelah menjual induk sapi untuk kebutuhan, mereka akan membeli ternak baru sebagai pengganti indukan.

\section{Kesimpulan}

Penggunaan asal semen dari BBIB Singo-sari dan BIB Lembang pada saat inseminasi tidak berbeda nyata $(p>0,05)$ terhadap nilai efisiensi reproduksi (CR, S/C dan CvR) pada sapi potong peranakan
Limousin di kecamatan Tikung, kabupaten Lamongan tahun 2016.

\section{Daftar Pustaka}

Atmakusuma, J., Harmini, R. Winandi. 2014. Mungkinkah Swasembada Daging Terwujud?. Risalah Kebijakan Pertanian dan Lingkungan. 1(2): 105-109.

Badan Pusat Statistik Kabupaten Lamongan. 2016. Statistik Daerah Kecamatan Tikung 2016. Diakses dan di download pada Maret 2017.

https://lamongankab.bps.go.id/website/pdf_ publikasi/Statistik-Daerah-

Kecamatan-Tikung-Tahun-2016.pdf

Fauziah, L.W., W. Busono dan G. Ciptadi. 2015. Performans Sapi Peranakan Ongole dan Peranakan Limousin pada Paritas Berbeda di Kecamatan Paciran Kabupaten Lamongan J. Ternak Tropika. 16(2): 49-54.

Hafez, E.S.E. 2000. Reproduction in Farm Animals. Edition 7th ed. Lippincott Williams \& Wilkins. Maryland. USA.165. Chapter 17 : Reproductive Failure in Females. Page 261-278.

Hariadi, M., S. Hardjopranjoto., Wurlina., H.A. Hermadi., B. Utomo., Rimayantim., I.N. Trianadan dan H. Ratnani. 2011. Ilmu Kemajiran Pada Ternak. Cetakan 1. Airlangga University Press. Surabaya. 62-63.

Herawati, T., A. Anggraeni, L. Praharani, D. Utami dan A. Argiris. 2012. Peran Inseminator dalam Keberhasilan Inseminasi Buatan Pada Sapi Perah. Informatika Pertanian. 21(2): $81-88$.

Pusat Data dan Sistem Informasi Pertanian Sekretariat Jenderal Kementerian Pertanian. 2015. Outlook Komoditas Pertanian Subsektor Peternakan Daging Sapi.

Susilawati, T. 2011. Tingkat Keberhasilan Inseminasi Buatan dengan Kualitas dan Deposisi Semen yang Berbeda pada Sapi Peranakan Ongole. Jurnal Ternak Tropika. 12(2): 15-24.

Winarso, B., Rosmiyati S dan C Muslim. 2005.Tinjauan Ekonomi Ternak Sapi Potong di Jawa Timur. Forum Penelitian Agro Ekonomi. 23(1): 61-71. 